\title{
ADMINISTRATIVE ENFORCEMENT OF THE LOTTERY BROADCAST PROVISION
}

ADMinistratrve action designed to control program content has long been the most controversial aspect of government regulation of radio broadcasting. The controversy stems primarily from the failure of Congress to indicate precisely whether, or to what extent, the Federal Communications Commission is empowered to supervise the program service of broadcasters.

Since access to radio broadcasting as a means of mass communication is peculiarly circumscribed by the limited number of transmission frequencies, ${ }^{1}$ a rational method for allocating these frequencies to broadcasters and for supervising their use is essential to maximum utilization of this medium. Recognizing this necessity, ${ }^{2}$ Congress has declared all broadcast channels to be public property, ${ }^{3}$ and has charged the Federal Communications Commission with the duty of protecting the public interest in the use of those channels. ${ }^{4}$ To enable the Commission to discharge this responsibility, Congress has vested it with exclusive power to grant permits for the construction of commercial transmitting facilities ${ }^{5}$ and to license broadcasters to operate over assigned frequencies. ${ }^{6}$ Exercise of these powers to regulate the technological phases of radio broadcasting is concededly a Commission function. ${ }^{7}$ There is sharp

1. While the total number of commercial broadcasting stations-AM, FM and TVhas tripled in the past three years, the demand for these types of transmitting facilities still exceeds the number of available channels. 14 FCC Ams. REP. 1-46 (1948). For nontechnical discussions of the physical aspects of radio broadeasting and the current allocation of frequencies, see FCC, Radio, A Public Prrarer (1940); Wartier, Radro arto Television LAw 221-7 (1948). It is possible, of course, that future scientific developments, by expanding the frequency spectrum or by maling possible simultancous transmissions over one frequency, may remove the unique physical characteristic of radio which has provided the essential justification for contemporary program controls. See Consarission on Freedons of the Press, A Free and Responsmee Press 33 (1947).

2. Communications Act of $1934 \$ \& 1,301,48$ Star. 1064, 1081 (1934), as amended, 50 Stat. 189 (1937), 47 U.S.C. $\$ \$ 151,301$ (1946) (hereinafter referred to only as the Communications Act). See also Sen. Rep. No. 772, 69th Cong., 2d Sess. (1926) (discussing the objectives of the Radio Act of 1927, predecessor of the present act).

3. Communications Act $\$ 301$.

4. While rejecting the system of government operation adopted by most other nations, Congress has likewise discarded free competition as a method for exploiting the medium of radio communication. Instead, private broadcasters are licensed to operate over assigned channels for three year periods. 47 CODE FED. REGS. \$3.34 (Supp. 1943). Grant or renewal of franchise depends upon a showing that the public interest will be served thereby. Communications Act $\$ 307$.

5. Communications Act $\$ 319$.

6. Communications Act $\$ \$ 307,309$ (a).

7. ". . . [T] he government has to license because of the technical nature of the industry. ... It gets in on all the technical phases." Hearings before Conntittce on Interstate Commerce on S. 814, 78th Cong., 1st Sess. 192 (1943) (statement of Neville Mifler, president of National Association of Broadcasters). An enumeration of the regulatory functions of the FCC may be found in 14 FCC ANs. REP. 25 (1948). 
disagreement, however, as to whether it was the sense of the legislators that the public interest was to be served by permitting unfettered private discretion in selection of program content, or whether the FCC was to hold licensees to an obligation to present the type of program matter it conceived to be most beneficial to the public.

Broadcasters, relying on a specific statutory provision prohibiting censorship by the $\mathrm{FCC}$, naturally espouse the more restrictive conception of the agency's functions. ${ }^{9}$ The Commission, on the other hand, has construed its responsibility as trustee of the public interest as requiring not only policing of the broadcast channels to prevent interference with radio transmission, but also as imposing an affirmative duty to insure that broadcasters exploit their privilege in a manner beneficial to the public welfare. ${ }^{10}$ Implicit in this conception of the Commission's functions is an obligation to require satisfactory program service from licensees, since exercise of the broadcasting franchise affects the public primarily through the matter transmitted. To secure such service, the Commission has considered itself empowered to deny or revoke licenses on the basis of evaluations of program service in terms of contributtion to the public welfare. ${ }^{11}$ From this power has evolved a method of general program supervision whereby the Commission, by merely expressing disapproval of particular programming practices in its opinions in licensing proceedings or in unofficial pronouncements, has in effect prescribed standards to which broadcasters are virtually compelled to conform through the implied threat that failure to comply may result in loss of franchise. ${ }^{12}$

8. Section $\mathbf{3 2 6}$ of the Communications Act provides that "Nothing in this Act shall be understood or construed to give the Commission the power of censorship over the radio communications or signals transmitted by any radio station, and no regulation or condition shall be promulgated or fixed by the Commission which shall interfere with the right of free speech by means of radio communication."

9. See, e.g., National Assoctation of Broadcasters, Broadcasting and the BrLI of RIGETs (1947).

10. "[The] wave lengths belong to the public, and there is a duty inherent that the operation on those wave lengths must be in the public interest." Hearings before Committee on Interstate Commerce on S. 814, 78th Cong., 1st Sess. 24 (1943). ". . . [T] The Commission has a statutory responsibility for the public interest, of which it cannot divest itself." FCC, Public Service Responsibilities of Broadcast licensees 55 (1946).

11. "... [T] [Te Commission believes it is entitled to consider the program service rendered by the various applicants, to compare them, and to favor those who render the best service" 2 FRC ANN. REP. 161 (1928), specifically reaffirmed in FCC, PUDho Service Responsibiltty of Broadcast Licensees 9-12 (1946). See also 7 FCC ANN. REP. 27 (1941).

12. The FCC has interpreted its duty to weigh the effect of a license grant on the public interest as permitting only comparative evaluation of the overall program service of competing applicants. FCC, PUblic Service Responstbility of Broddcast LicensEES 54-5 (1946). Hearings before Committee on Interstate Commerce on $S .814$, 78th Cong., 1st Sess. 43-4 (1943). But in appraising overall service the FCC has, of necessity, specified the particular types of programs which have been weighed adversely in arriving at a general evaluation. See note 16 infra. Since the courts have afforded 
While claiming and occasionally exercising broad regulatory powers, the FCC, chastened by charges of censorship, has proceeded cautiously into the area of program supervision. ${ }^{13}$ Although measures directed at controlling the program service of broadcast licensees may serve to discharge the Commission's obligation to the public, they are also a source of potential conflict with the statutory ban against censorship and with the constitutional guarantee of free speech-a conflict which the courts have never definitively reconciled. ${ }^{14}$

the Commission broad discretion to determine what types of broadeasting activity are in the public interest, see, e.g., FCC v. WOKO, 329 U.S. 223 (1946), the deterrent effect of such expressions of disapproval is virtually equivalent to a flat pronouncement that presentation of these types of programs may be grounds for withdrawal of license. See, e.g., note 88 infra.

The Federal Radio Commission, predecessor to the FCC, revolied the licenses of two stations solely on the ground that they were presenting programs detrimental to the public interest, and in each instance was upheld. KFKB Broadeasting Ass'n v. FRC, 47 F.2d 670 (App.D.C. 1931) (dubious medical advice); Trinity Mrethodist Church, South, v. FRC, 62 F.2d 850 (App.D.C. 1932) (outspoken verbal attacks on loeal dignitaries). While operating under identical statutory provisions, the FCC has rejected the device of revocation before license expiration and has used renewal proceedings as the forum for reviewing program service. For general discussions of FCC program supervision, see Segal, Recent Trents in Censorship of Radiobroadeast Programs, 20 Rocky IIT. L. REv. 366 (1948); Comment, Radio Program Controls: A Network of Inadequacy, 57 Yale L. J. 275 (1947); Note, Goucrument Control of the Contents of Radio Programs, 47 CoL. I. Rev. 1041 (1947). See also Warites, Radio AND Television LAw, c. III (1948). Yet the FCC stoutly maintains that "We have not exercised either a negative or affirmative control over any program or proposed program." Hearings before Conmittee on Interstate Commerce on S. 814, 78th Cong. 1st Sess. 25 (1943) (Statement of Commissioner Fly, then Chairman of the FCC). But see, e.g., note 16 infra.

13. See, e.g., Steparann, Radio's Second Chance 10 (1946). "... [T] the FCC is distinguished, so far, more for its acts of omission than those of commission. It has the meekness of the lamb, the pace and caution of the tortoise, rather than the rapacity and the swift spring of the wolf." See also Comment, Radio Program Controls: $A$ Network of Inadequacy, 57 YALE L. J. 275 (1947).

14. The FCC's view is not only that the Commission exercises no control over programs (see note 12 supra), but more specifically that it "exercises no nower of censorship over radio communications. Thus it neither requires the breadeasting of particular programs nor bans them; program selection is in the first instance the function of the broadcasters licensed to operate stations." 7 FCC Arrs. REP. 27 (1941). This conception of censorship only as a direct prior restraint was indorsed by the courts in the two instances in which actions of the Federal Radio Commission vere attacked as censorial. See KFKB Broadcasting Ass'n v. FRC, 47 F.2d 670, 672 (App.D.C. 1931) ; Trinity IIethodist Church, South, v. FRC, 62 F.2d 850, 853 (Agp.D.C. 1932). It would seem, however, that this view conflicts with the Supreme Court's declaration that immunity from previous restraint "cannot be deemed to exhaust the conception of the liberty guaranteed by state and federal constitutions." Near v. Minnesota, 283 U.S. 697, 714-5 (1931).

Whatever the accurate definition of censorship, judicial coniusion as the estent to which the FCC may control program service is still evident. Comfarc FCC v. Sanders Bros. Radio Station, 309 U.S. 470, 475 (1940) ("The Commission is given no supervisory control of the programs. ... In short, the broadeasting field is open to 
Confronted with this apparent dilemma, the FCC has imposed few effective restraints on programming practices, ${ }^{10}$ and has reproved only the most objectionable types of program subject matter. ${ }^{16}$ Determination of program content has been left largely to the discretion of the broadcasters. ${ }^{17}$

\section{Control of the GIVEaways}

One of the FCC's boldest projects for control of program subject matter was outlined in a recent Commission announcement ${ }^{18}$ proposing the promulgation of rules calculated to ban many of the currently numerous and successful giveaway programs. ${ }^{19}$ The proposed action is of interest not only because

anyone, provided there be an available frequency over which he can broadcast without interference to others, if he shows his competency, the adequacy of his equipment, and financial ability to make good use of the assigned channel."), with National Broadcasting Co. v. United States, 319 U.S. 190, 215 (1943) ("But the Act does not restrict the Commission merely to supervision of the [radio] traffic. It puts upon the Commission the burden of determining the composition of that traffic.")

The confusion essentially arises from a failure or unwillingness to acknowledge frankly the supervisory effect of FCC appraisal of program service in licensing, and to test such action against the statutory and constitutional bars against governmental restraints on free speech. If the supervisory character of such action were conceded, the action would still seem valid in the light of the statutory prohibition against censorship, since this provision was copied directly from the Radio Act of 1927, 44 STAT. 1162 (1927), after the Federal Radio Commission, with judicial approval, had asserted the same authority under the latter provision. See notes 11 and 12 stupra. Whether this type of program supervision squares with the First Amendment still seems an open question.

15. See, e.g., Comment, Radio Program Controls: A Netzuork of Inadequacy, 57 YALE L. J. 275, 294 (1947); SIEPMANN, op. cit. supra note 13, at 68. As distinct from criteria directly concerned with the subject matter of individual programs, the FCC has established standards governing the general programming policies of broadcasters dealing with matters such as excessive reliance on sponsored network programs. These standards have been expounded for the most part in the so-called Blue Book. FCC, Public Service Responsibility of BroadCast Licensees (1946).

16. Examples are: (1) programs offensive to religious sensibilities; (2) personal attacks or defamatory statements; (3) fortune-telling; (4) solicitation of funds; (5) offensive children's programs; (6) astrology; (7) false or misleading advertising. See Warner, Radio and Television Law, c. III (1948); Landry, Who, What, Why is RAdro? 52 (1942) ; Note, Radio Censorship and the Federal Communications Commission, 39 CoL. L. REv. 447 (1939).

17. See Comment, Radio Program Controls: A Network of Inadequacy, 57 YauE L. J. 275 (1947) ; FCC, Public Service Responsibility of BrondCast Licensees 54-6 (1946).

18. FCC, Notice of Proposed Rule Making, Docket No. 9113, 13 FED. REG. 4748 (1948); FCC, Supplemental Notice of Proposed Rule Making, 13 FED. REG. 5075 (1948). Hearings were held on the proposal on Oct. 19, 1948, but a decision has not yet been rendered.

19. Giveaway programs can be defined comprehensively only as programs involving some type of scheme whereby a limited number of prizes are awarded to members of the studio or listening audiences. While the first of these programs, Pot O'Gold, appeared on a major network about ten years ago, it is only within the past two years 
of its potential impact on the radio industry, but also because it raises unique problems both as to the Commission's jurisdiction to undertake any action with respect to this type of program and as to the specific technique which may be employed to effect control.

In addition to the public interest standard of the general licensing provisions, under which the Commission has evolved its own criteria for appraising, and effectively supervising, program service, Congress has imposed several specific statutory restraints on private discretion in determination of program content by prohibiting particular types of program matter.20 While in the case of most of these standards Congress has failed to provide specific enforcement power for the FCC, ${ }^{21}$ the Commission has, nevertheless, oceasionally sought to implement them. ${ }^{22}$ The Commission, however, has given no clear indication as to whether it regarded the specific provisions as themselves authorizing these actions or as merely indicating standards for the administration of its general licensing function. ${ }^{23}$ In its proposed attacl on the

that this genre has become one of radio's most popular forms of entertainment. U.S. News, Aug. 20,1948, p. 19. The great variety of radio giveaway schemes is indieated in an article describing the formats of all the network giveaways in Radio Altum Mlagezine, Spring, 1949, p. 65 . Forty such programs are carried by the four major networls, while probably several hundred more are being presented by individual stations. 2N.Y. Times, Aug. 6, 1948, p. 1, col. 6. Many of these would be barred by the Commission's proposed rules. See note 25 infra. For discussions of the entertainment value and popular appeal of the giveaways, see, e.g., James, The Radio Giverasuay, 67 Ars. MEs:cuRY 430 (1948); Gould, Jack Benny or Jachpot, N.Y. Times, Aug. 15, 194\$, §6, p. 16.

20. Prior to Sept. 1, 1948, the sections of the Communications Act specifically relating to the contents of radio programs were the following: (1) \$315, requiring breadcasters to offer equal facilities to opposing candidates for public office; (2) $\$ 316$, forbidding the broadcast of information relating to lotteries, gift enterprises or similar schemes; (3) $\$ 317$, requiring that all sponsored programs be announced as such; (4) $\$ 325(a)$, forbidding the rebroadcast of another station's program without the express authorization of that station; (5) $\$ 326$, the last sentence of which forbids the breadcast of obscene, indecent or profane language. On Sept. 1, 1948, Section 316 and the last sentence of Section 326 were removed from the Communications Act and placed in the Criminal Code. See note 24 infra.

21. The FCC is required to effectuate Section 315 through the promulgation of rules and regulations. Former Sections 316 and 326 were, and in their present form are, phrased as penal provisions with no specific reference to Commission responsibility for enforcement. Sections 317 and 325(a) are merely cast in prohibitive phrascology with no reference to the means of enforcement. However, they acquire the force of criminal sanction through Section 501, which declares the breach of any prohibitive or compulsive provision of the Act to be a penal offense.

22. See notes 35,53 and 55 infro.

23. Typical is the decision in WRBL Radio Station, 2 F.C.C. 687 (1936), in which the Commission concluded that a program broadcast by an applicant for license renewal violated both Section 316 and a state anti-lottery law. Although suggesting that such conduct did not appear to advance the public interest, the Commission finally granted renewal because of otherwise meritorious service. In general, the FCC appears to have considered transgressions of these proscriptive statutory provisions in the same vay in which it has weighed conduct improper only because the FCC has found it detrimental 
giveaways, the FCC, rather than relying solely on the touchstone of public interest, has drawn statutory support from the provision declaring the broadcast of lotteries to be a criminal offense-a provision originally enacted as Section 316 of the Communications Act of 1934, but recently transferred to Section 1304 of the Criminal Code in an omnibus recodification measure. ${ }^{24}$ While the precise theory by which jurisdiction is asserted is not fully explained, the Commission's proposal is clearly predicated on the premise that many giveaway programs violate the lottery broadcast provision, ${ }^{25}$ and that the Commission is empowered to utilize its administrative weapons to prevent the broadcast of such illicit programs. ${ }^{26}$

To effect the stricture against lottery broadcasts, the FCC apparently intends to abandon the informal supervisory technique of enunciating and enforcing program standards by indirection, preferring the formal promulgation of rules spelling out the norms which the Commission will employ to identify lottery broadcasts. ${ }^{27}$ While the proposed rules are cast in purely

to the public interest. In view of this fact, a former General Counsel of the FRC commented that "Congress might as well have spared itself the trouble of enacting the specific provisions.... The Commission would have arrived at the same result anyway, and in most cases, by the use of the vague standard, has greatly expanded the prohibitions found in the statute." Caldwell, Legal Restrictions on the Contents of Broadcast Programs, 9 AIR L. REv. 229, 237 (1938). On the other hand, it may well be argued that failure to recognize specifically a direct duty of enforcement in the Commission has vitiated the statutory prohibitions and has resulted in a cautious and uncertain enforcement policy which has checked only the most gross infractions of these provisions. See, e.g., Comment, Radio Program Controls: A Network of Inadequacy, 57 YALE L. J. 275, 287 (1947).

24. Pub. L. No. 772, 80th Cong., 2d Sess. (June 25, 1948, effective Sept. 1, 1948).

25. The FCC's proposal declares that the Commission will consider a program to be a lottery if valuable prizes are awarded on the basis of chance to winners who are required (1) "to furnish any money or thing of value or are required to have in their possession any product sold, manufactured, furnished or distributed by a sponsor of a program broadcast on the station in question; or (2) ... to be listening to or viewing the program in question on a radio or television receiver; or (3) ... to answer correctly a question, the answer to which is given on a program broadcast over the station in question or where an aid to answering the question correctly is given on a program broadcast over the station in question [prior broadcast of a question to be considered an aid in answering] ... ; or (4) ... to answer the phone or write a letter if the phone conversation or contents of the letter ... are broadcast by the station." FCC, Notice of Proposed Rule Making, supra note 18, Appendix.

This definition embodies the three factors long accepted as essential to a finding that a particular scheme is a lottery-prize, chance and consideration. Post Publishing Co. v. Murray, 230 Fed. 773 (1st Cir. 1916) ; Horner v. United States, 147 U.S. 449 (1893). The question of the accuracy of the FCC's classification of these types of programs as lotteries is beyond the scope of this comment.

26. "These proposed rules are designed to assist the Commission, licensecs, and other interested persons in giving effect to the public policy embodied in the determination of Congress that the United States should not 'permit any radio station licensed and regulated by the government to engage in any such unlawful practices [the broadcast of lotteries].'" FCC, Supplemental Notice of Proposed Rule Making, supra note 18, \$4. 27. See FCC, Supplemental Notice of Proposed Rule Making, supra note 18, §5. 
definitional phraseology, they manifestly embody the Commission"s determination to enforce them by administrative action.

Both the FCC's claim to jurisdiction over lottery broadcasts and its proposed method of administrative enforcement have been challenged as exceeding the Commission's authority. ${ }^{28}$ The basic objection to the Commission's assertion of jurisdiction is that since Section $130 \pm$ is a criminal provision containing no specific delegation of correlative enforcement powers to the FCC, criminal prosecution is the exclusive means of compelling brosdcasters to refrain from transmitting lottery programs.29 Opponents of the FCC's proposal further contend that even if the Commission were empowered to enforce the lottery broadcast provision, it could do so only by considering violations of that provision in passing on license applications, and could not enact rules embodying its definition of lottery broadcasts ${ }^{30}$ - the argument running that such rules would be a direct means of enforcing Section $130 \pm$ of the Criminal Code, while the Commission is confined to making rules "to carry out the provisions of this Act."31 The succeeding discussion will be concerned with analyzing these two aspects of the Commission's proposal, leaving aside the question of the accuracy of the FCC's definition of lottery programs. ${ }^{32}$

\section{BASES OF JURISDICTION}

While the broadcast of lotteries has been outlawed for fifteen years, the questions of whether the FCC has authority to effect that prohibition, and, if it has, what the nature of that authority is, have never been settled.3 Nonetheless, the Commission, even when preaching its lack of actual enforcement power, 34 has in practice enforced the lottery broadcast provision by occasional

28. Adrerican Broadcasting Co., Brief in Opfosition to the Protosed Rutes (Sept. 24, 1948). Seven other briefs were submitted in opposition to the proposal and one in favor. The ABC brief presented the most comprehensive argument against the Commission's assertion of jurisdiction.

29. ABC, BRIEF, supra note 28 , at 5-11.

30. Id. at 19-32.

31. Communications Act $\$ 4(i)$.

32. While the accuracy of the FCC's definition of types of lottery programs, suspra note 25 , has been vigorously challenged, e.g., ABC, BRIE, supra note 28 , at 33-56, a more fundamental question is whether the FCC would have authority to issue the proposed rules if the requirement as to definitional accuracy were met either in that (a) the FCC's definition of lotteries did in fact correspond with the criminal definition or (b) it was not required so to correspond. See p. 1106 infra.

33. The courts have never considered this problem. Opinions of commentators have differed: compare WARNER, RADIo AND TELEVISIOst LAW 341 (1948) (FCC should take no action with respect to lottery broadeasts); Hearings before Conmintec oni Interstate Commerce on H.R. 5497, 77th Cong., 2d Sess. 644-6 (1942) (only adjudicated violations of the lottery broadeast provision may be considered in licensing proceedings); Socolow, Law of Radio Broadcastrwg 889, 1023-5 (1939) (FCC may consider unadjudicated violations).

34. "... [C]ases which involve violation of the specific injunction against programs containing lottery information ... are investigated by the Commission and re- 
consideration of violations in licensing proceedings ${ }^{36}$ and by "discouraging" offenders through informal expressions of disapproval. ${ }^{36}$ With the recent mushrooming of the giveaways, however, the Commission has found it necessary to take an affirmative stand in order to meet the problem head on. ${ }^{37}$

An important consideration in evaluating the FCC's claim to jurisdiction is whether that agency can best effectuate the statutory ban against the broadcast of lotteries. ${ }^{38}$ Since these broadcasts are denominated crimes, the Department of Justice may, of course, enforce the provision by prosecuting offenders. But criminal prosecution as a means of inhibiting such offenses, as with "white collar" crimes generally, ${ }^{30}$ has not proven adequate. ${ }^{40}$ The more

ferred to the prosecuting authorities for appropriate action." 6 FCC ANN. REP. 55-6 (1940).

35. In two instances the FCC found that programs broadcast by applicants for renewal of license were lotteries, but granted renewal in view of otherwise meritorious service. WRBL Radio Station, 2 F.C.C. 687 (1936) (see supra note 23); KXL Broadcasters, 4 F.C.C. 186 (1937). In one competitive licensing proceeding there was indication that violation of the radio lottery provision was one of the grounds for denial of license to an applicant. Metropolitan Broadcasting Corp., 5 F.C.C. 501 (1938), 8 F.C.C. 557 (1941). Since initiating its investigation of the giveaways in 1946, the Commission has sidestepped the issue of lottery broadcasts in licensing proceedings. Capital Broadcasting Co., 3 Pike \& Fischer Radio Reg. 310 (1946); Coastal Broadcasters, 4 Pure \& FISCHER RADIO REg. 751 (1948).

36. This has been accomplished primarily through the manner in which the FCC has handled the numerous complaints from listeners and persons otherwise concerned that particular programs are lotteries. 6 FCC ANN. REP. 57 (1940). When the misconduct charged in a complaint has appeared of sufficient seriousness to the FCC, it has either initiated an investigation, or, more commonly, called the objection to the attention of the broadcaster with some indication of the Commission's concern. Ibid. In view of the FCC's avowed disapproval of lottery broadcasts, see note 35 supra, a licensee gentrally discontinues a practice upon learning of the complaint and the Commission's attitude rather than risk full investigation and its attendant publicity or even loss of license. Hearings before Committee on Interstate and Foreign Commerce on H. R. 5497, 77th Cong, $2 \mathrm{~d}$ Sess. 644-5 (1942).

37. To stress its new determination to cope with the giveaways, the Commission, simultaneously with the announcement of the proposal to enact lottery broadcast rules, released a Hearing Examiner's report recommending that a declaratory ruling be issued pronouncing a program which had been investigated to be a violation of the radio lottery provision. Northern Virginia Broadcasters, 4 Pike \& Fiscuer Radio Reg. 660 (Aug. 5, 1948). The Commission, however, retreated from the ground on which these initial assertions of jurisdiction were based upon discovery that Section 316, on which both actions rested, had been removed to the Criminal Code a month previously. N.Y. Times, Aug. 22, 1948, p. 1, col. 8; FCC, Supplemental Notice of Proposed Rule Making, note 18 supra.

38. See p. 1097 supra.

39. See Sutherland, White Collar Criminality, 5 Am. Socrological Rev. 1 (1940) and Sutherland, Crime and Business, 217 Annals of Am. Acad. of Pol. \& Soc. Sctence $112,113-4$ (1941).

40. There has never been a criminal prosecution for violation of the lottery broadeast provision. While the FCC in passing on license applications has formally declared three programs to be violations of Section 316, see note 35 supra, no steps were taken toward 
effective and expeditious way to prevent the broadcast of lotteries would appear to be recognition of a parallel duty of enforcement in the specialized agency primarily responsible for implementing public radio policy. Certainly FCC authority to check such broadcasts would not expose broadcasters to extraordinary administrative control, since the Commission imposes identical restraints upon the transmission of matter presumably less socially harmiul than that stigmatized as criminal.11 Opponents of the FCC's proposal have not contended that administrative enforcement of the lottery broadcast provision would be ineffective or inadvisable, but rather maintain only that Congress has not, in fact, granted authority to the Commission to undertake such action. ${ }^{42}$

Congress's failure to delegate administrative enforcement powers specifically to the FCC necessitates closer analysis of the statutory sources of the Commission's authority to determine whether its assertion of jurisdiction is tenable. Two grounds are available on which the Commission may seels to establish its claim. On the one hand, it may contend that enforcement authority is derived directly from Section 316 of the Communications Act, and that the recent transfer of that section to the Criminal Code has not altered the mandate. $^{.3}$ Alternatively, the Commission may assert that its duty to license

criminal prosecution of the offenders. In 1940, the FCC did request the Department of Justice to prosecute the broadcasters of seven programs which the Commission believed were violative of Section 316. The Department refused to institute prosecutive action, but significantly refrained from stating that this decision was based on a belief that the programs were not lotteries. $4 \mathrm{FED}$. Cosr. BAR J. 169, 195 (1940). Experience under the postal lottery statute, see note 50 infra, similarly reveals that eniorcement responsibility has been assumed primarily by the Postal Department rather than the Department of Justice. See, e.g., Communication to the Yale Law Jourasal from the Office of the Solicitor, Post Ofice Dept., Mfay 31, 1949.

The inaction of the criminal enforcement authorities might be explained in sereral ways : that the vastness of the area of conduct they must patrol makes possible prosceution only of the most gross offenses; that the difficulty of obtaining conviction for misconduct of this type, which carries no particular moral stigma, warrants prosecution only of the most culpable violations; that the prosecuting officials rely on administrative regulation as the first line of attack or activity of this type; and finally, that the Department of Justice believes there have been no violations.

41. See notes 12 and 16 supra.

42. See briefs submitted in opposition to the proposed rules, note $2 S$ sspra.

43. This ground was initially advanced by the Commission in the original Notice of Proposed Rule Mraking, stpra note 1\$, $\$ 2$, and in the Hearing Examiner's report in Northern Virginia Broadcasters, 4 Pike \& Frscher Radro Reg. 660 (1948)-based, however, on the erroneous belief that Section 316 was still part of the Communications Act. This ground, implicit in the original notice, was made explicit in the Hearing Esaminer's report by the pronouncement that "The respondent's conduct is not here under serutiny" to determine the merit or lack of merit, from the standpoint of public interest, convenience and necessity, in the particular program called in question in the respondent's uverall program service... [O]ur discussion is limited solely to the challenged program in relation to the anti-lottery provision of the Communications Act." 4 PIFE \& FIscrer RAdTo REG. 660, 666 (1948). 
broadcasters in the public interest requires denial of licenses to applicants who fail to comply with the public policy expressed in the radio lottery provision of the Criminal Code. ${ }^{44}$ As theories of jurisdiction these two grounds essentially differ only on the conceptual level, since affirmation of either would have the practical consequence of acknowledging the Commission's authority to take action which would effectively restrain the broadcast of lotteries. Apart from the conceptual difference, the latter ground might, if accepted, be construed as limiting the Commission to seeking enforcement by exercise of its licensing power. ${ }^{45}$

\section{Jurisdiction through Section 1304}

The legislative history of the lottery broadcast provision appears to support the view that the FCC was directly empowered to effectuate that section of the Communications Act. A clause in the original draft of Section 18 of H.R. 7716,46 from which Section 316 was directly copied, ${ }^{47}$ provided that "no radio station license shall be suspended or revoked on account of any such violation [of the lottery broadcast provision]." This clause was deleted by unanimous vote in the Senate, and the bill in this amended form was passed by both houses. ${ }^{48}$ Senate discussion of the motion to delete this clause emphasized the legislators' intent that the FCC should compel compliance with the lottery broadcast provision by denying licenses to transgressors. ${ }^{40}$ While obviously buttressing the claim to jurisdiction derived indirectly through the licensing powers, these expressions of legislative purpose also imply recognition of a direct responsibility of the Commission to effectuate the radio lottery provision. And of equal significance are Congressional statements that Section 316 was intended to grant the FCC the same authority to prevent dissemination of lottery information by radio as had been specifically delegated to the postmaster to exclude such matter from the mails. ${ }^{50}$ That this expressed

44. When the removal of Section 316 was called to the FCC's attention, N.Y. Times, Aug. 22, 1948, g. 1, col. 6, the Commission hastily shifted to this jurisdictional base. FCC, Supplemental Notice of Proposed Rule Making, stipra note 18, $\$ \$ 3,4$ (Aug، 26, 1948).

45. See note 98 infra.

46. 72d Cong., 2d Sess. (1933).

47. See Conference Report on Communications Act of 1934, H.R. REP. No. 1918, 73d Cong., 1st Sess. (1934).

48. Subsequently to be pocket-vetoed by President Hoover.

49. Senator George, in presenting the motion to delete this clause, said, ". . [ [F]or repeated or continued violations, the license of a broadcasting station might well and properiy be revoked. With this language in the provision the power to revoke even for flagrant violations would be denied." 76 CoNG. Rec. 3767-8 (1933). Senator Dill, chairman of the committee reporting the bill, expressly concurred in this affirmation of the FCC's authority under the radio lottery provision. Ibid.

50. Transmission of lottery information through the mails is a criminal offense. 18 U.S.C. $\S 1302$ (1948). But in addition to criminal prosecution as a means of enforcement, Congress has provided for parallel administrative enforcement action by specifically empowering the postmaster to bar lottery information from the mails. 39 U.S.C. $\$ 259$ (1946) and to forbid payment of postal money orders to persons conducting lotteries. 39 
intent was embodied in the text of the Communications Act is demonstrated by the several sections which confirm FCC responsibility for effectuating all provisions of the Act. ${ }^{51}$

The FCC's claim to jurisdiction under Section 316 finds further support in analogous exercises of power by the Commission. Sections 317 and 325 of the Communications Act, requiring identification of sponsored programs and prohibiting unauthorized rebroadcast of another station's programs, contain no specific delegation of enforcement authority to the FCC. Under Section 501 penal sanctions are provided for violation of these sections. Yet the Commission has compelled compliance with these provisions both by issuing rules specifically defining proscribed practices ${ }^{32}$ and by weighing infractions in licensing proceedings. ${ }^{33}$ The provision declaring the broadcast of obscenity to be a criminal offense-formerly part of Section 326, but, like Section 316, recently removed to the Criminal Code ${ }^{54}$-likewise makes no specific grant of enforcement power to the FCC. The Commission, nevertheless, has assumed primary responsibility for enforcement of this provision both by exercise of its licensing powers ${ }^{55}$ and by the informal methods of investigation and warn-

U.S.C. $\$ 732$ (1946). Despite the absence of specific delegation, there is evidence that Congress intended to grant equivalent powers to the FCC to cheek the broadeast of lotteries. Section 316 was explicitly designed after the postal lottery provision. SEr. Rep. No. 1045, 72d Cong., 2d Sess. (1933). See Haley, The Broadcasting and Postal Lottcry Statutes, 4 GEO. WASE. L. REV. 475 (1936). Rather than pointing to an intent to malke a vital departure from the postal lottery pattern by eliminating administrative enforcement, Congressional statements suggest that the parallelism includes this essential feature. "... [T] he broadcast of [lottery] information is unfair to newspapers which are forbidden the use of the mails if they contain such information ... [T] [Te language of the new section more nearly places radio stations on the same basis as newspapers in connection with broadcasting information as to lotteries." SEN. REP. No. 1045, 72d Cong., $2 d$ Sess. (1933). See also 75 Cong. Rec. 3684, 3704 (1932); 76 Corsc. Rec. 3767 (1933).

51. Section $303(\mathrm{r})$ requires the FCC to make rules and regulations "to carry out the provisions of this Act." Section 403 empowers the Commission to investigate any matter relating to "the enforcement of any of the provisions of this Act." In the absence of any constitutional bar to the delegation to the FCC of power to effectuate Section 316, the clear import of the wording of these provisions would seem to constrain recognition of enforcement responsibility in the Commission.

52. FCC Regs. 3.189, 3.191, 47 Code Fed. Reas. $\$ 3.408$ (Cum. Supp. 1938), 47 Codz FED. REGS. $\$ 3.409$ (Supp. 1944), both as recodifed by 13 FED. REG. 422 (1948).

53. Breach of Section 317 was weighed adversely in Charles C. Carlson, 3 PIKE \& Fischer Radio Reg. 18S7 (1948) ; Albuquerque Breadcasting Co., 3 PIEE \& Fiscuers RAdro Reg. 1820 (1946). Non-compliance with Section 325(a) was considered in A. E. Newton, 2 F.C.C. 281 (1936).

54. Pub. L. No. 772, 80th Cong., 2d Sess. (June 25, 1948, effective Sept. 1, 1948).

55. Under the Federal Radio Commission revocation of one station's license vas based primarily on violation of $\S 326, I n$ re Schaeffer, FRC Docket No. 5223 ( 1 isy 30, 1930), and in another instance a station was placed on probation for use of profanity. U.S. Daily, Jan. 25, 1930. Broadcast of obscenity was considered by the FCC in Seroggins \& Co. Bank, 1 F.C.C. 194 (1935) ; Knickerbocker Broadcasting Co., Docket 2916 (Aug. $6,1935)$. 
ing. ${ }^{56}$ Although none of the exercises of power under these sections have received formal judicial approval, they bear such weight as may be ascribed to established administrative usage. ${ }^{57}$ Of particular significance is the FCC's assumption of jurisdiction under Section 326, since that section was re-enacted unaltered in the Communications Act of 1934 after the Federal Radio Commission had asserted authority under the same provision in the Radio Act of 1927.58 While the FCC has never precisely expounded the theory of jurisdiction on which it based these actions, the resort to measures stuch as the promulgation of regulations suggests that the Commission was motivated by a sense of obligation to effect the purposes of these sections directly. ${ }^{60}$

Although the above considerations lend weight to the FCC's averment of jurisdiction derived directly from Section 316, opponents of the Commission's proposal maintain that removal of that section to the Criminal Code obliterated any authority the agency might previously have derived from it. ${ }^{00}$ Courts, however, have uniformly held that revisions and consolidations of the statutes do not effect a substantive change in the law unless an intention to that effect is clearly expressed by the legislature. ${ }^{61}$ Rather than supplying evidence of such intent, Congressional reports specifically disavow any purpose to effect substantive changes by the recodification of the Criminal Code. ${ }^{62}$ Even if divestment of powers were not considered substantive, it seems unlikely that a court would construe a legislative act designed merely to achieve a more rintional grouping of statutory provisions within the Criminal Code as altering the original scheme of enforcement.

Nevertheless, although the FCC initially grounded its lottery broadcast project directly on Section 316, it hastily concluded, upon belated discovery of the

56. See, e.g., the FCC's castigation of NBC for the Mae West Adam and Evc broadcast, WARNER, op. cit. supra note 12 , at $338 \mathrm{n} .14$, and threat of license reprisals to stations which had carried the program. N.Y. Times, Jan. 15, 1938, p. 1, col. 2.

57. See Gellhorn, Administrative Law 203-5 (2d ed. 1947); Crawford, Construction of Statutes 393-4 (1940) (cases cited).

58. The portion of Section 326 of the Communications Act prohibiting obscenity was copied directly from Section 29 of the Radio Act of 1927, 44 STAт. 1172 (1927). Tho FRC had asserted effective jurisdiction under Section 29 in two cases prior to the time it was re-enacted as part of the Communications Act. See note 55 supra. The wcight to be given such legislative confirmation of administrative interpretation of a statute is discussed in CRAWFORD, op. cit. supra note 57, at 404.

59. Since the regulations relating to sections 317 and 325 (a), see note 52 supra, proscribe defined types of broadcasting activity, and do not merly announce that such activity will be deemed contrary to the public interest, they may well be considered to implement those provisions rather than the licensing provision.

60. ABC, BRIEF, supra note 28, at 13 .

61. See, e.g., United States v. Ryder, 110 U.S. 729,740 (1884).

62. See Sen. Rep. No. 1620, 80th Cong., 2d Sess. 1 (1948): "The original intent of Congress is preserved." See also statements by Charles J. Zinn, Law Revision Counsel to House Committee on Judiciary, emphasizing the fact that no substantive changes in existing law were intended by the recodification. Hearings before Subcommilteg No. 1 of House Judiciary Committee on H.R. 1600 and H.R. 2055, 80th Cong,, 1st Sess. (1947). 
transfer of that section, ${ }^{63}$ that the removal pulled the statutory props from under its original proposal. It therefore issued a supplementary notice shifting to the general licensing provisions as the statutory basis for its proposed action. ${ }^{64}$

\section{Jurisdiction through the Licensing Provisions}

The Commission may follow either of two lines of reasoning to establish its authority to weigh infringements of the lottery broadcast provision in considering applications for licenses. First, the Commission's duty to grant and renew broadcast licenses so as best to serve the public interest requires appraisal of the "character" qualifications of applicants. ${ }^{63}$ Several court decisions confirm the right of the Commission to view non-compliance with public policies expressed in other statutes as reflecting detrimentally on the fitness of an applicant. ${ }^{66}$ In the case of a criminal statute, the courts have indicated that non-compliance need not be evidenced by a conviction. ${ }^{67}$ Thus the FCC may soundly assert authority to consider unadjudicated violations of the lottery broadcast provision as indicating that an applicant is unfit to be entrusted with a broadcasting franchise.

Second, the Commission, in proceedings to renew or revole licenses, may determine that the broadcast of lotteries is a type of program service not in the public interest; and it may therefore withdraw the license of a broadcaster who transmits such programs because he has failed to meet the responsibilities of his trust. Denials of licenses on the basis of evaluations of program service

63. N.Y. Times, Aug. 22, 1948, p. 1, col. 6.

64. FCC, Supplementary Notice of Proposed Rule MFaking, susra note $18, \S \S 3,4$. N.Y. Times, Aug. 28, 1948, p. 17, col. 5.

65. Communications Act $\S 30 S(b)$; Miester v. United States, 70 F.Supp. 118 (E.D.N.Y. 1947), aff'd, 332 U.S. 749 (1947) ; FCC v. WOKO, 329 U.S. 223 (1946).

66. Miester v. United States, supra note 65 (court upheld FCC's denial of applieation for construction permit based in part on ground that applicant had violated the Pure Food and Drug Act and Price Control Act). See also MicLean Trucling Co. v. United States, 321 U.S. 67 (1944) ; Southern Steamship Co. v. NLRB, 316 U.S. 31 (1942). In the latter case the Court, in negating an NLRB order issued without consideration of the way in which a criminal statute related to the matter at hand, said; ". . . [T] he Board has not been commissioned to effectuate the policies of the Labor Relations Act so single-mindedly that it may wholly ignore other and equally important Congressional objectives. Frequently the entire scope of Congressional purpose calls for careful accommodation of one statutory scheme to another, and it is not too much to demand of an administrative body that it undertake this accommodation without excessive emphasis upon its immediate task." Id. at 47.

67. In Miester v. United States, supra note 65, at 122, the court stated that "It might indeed be most inadvisable from the public viewpoint to entrust the operation of a radio station to a person ... evidencing disregard for regulatory laws, even though the had never been convicted of a felony." While the applicants in this instance had been involved in litigation concerning alleged violations of criminal statutes, it hardly seems probable that this factor would be selected by the courts as a criterion for defining the extent of an individual's rights or the range of the FCC's administrative discretion. See also Southern Steanship and MicLean cases, note 66 supro. 
in terms of contribution to the public welfare have been upheld even where the types of program matter stigmatized have not been prohibited by statute. ${ }^{08}$ $A$ fortiori, where a broadcaster transmits a type of subject matter thus prohibited, it would seem that the FCC may safely judge that his operations fall below the necessary level of public service.

Two points should be noted in connection with the FCC's current contention that the general licensing provisions provide the source of its jurisdiction over lottery broadcasts. First, with respect to the second possible rationale for this claim to jurisdiction-that lottery programs are an unsatisfactory type of broadcasting service-it should be observed that the Commission might reach its judgment as to the effect of such broadcasts on the public without reference to the radio lottery provision of the criminal code by undertaking to determine independently that giveaway programs are detrimental to the public interest. ${ }^{00}$ By so doing, the Commission would avoid the present challenge to its jurisdiction, ${ }^{70}$ and free itself of the obligation to restrict its attack to those broadcasts which fall within the criminal definition of lottery. ${ }^{71}$ But such a determination would inevitably involve the same moral considerations and evaluation of public welfare which weighed in the Congressional decision to ban lottery broadcasts. $^{72}$ Rather than ignore this express legislative determination, the FCC has relied upon the statutory prohibition as the criterion by which it will judge effect on the public. ${ }^{73}$ This forthright approach, in addition to exposing the proposal to technical challenges as to jurisdiction, will probably limit the Commission to action against only those giveaway programs falling under the criminal ban.

Second, it should be noted that the FCC might frame the proposed rules either to make denial or revocation of license mandatory upon determination that a broadcaster has transmitted a lottery, or alternatively, merely to indicate that the broadcast of lotteries will be weighed adversely in reaching a general determination as to whether a broadcaster has operated in the public interest. If jurisdiction is claimed only through the licensing provisions, the latter form

68. See notes 12 and 16 supra.

69. See, e.g., Marks, Legality of Radio Giveazeay Programs, 37 Geo. L. J. 319 (1949). This course was followed by the FCC in issuing the Chain Broadcasting Regulations. See p. 1116 infra.

70. Since the challenge is based on the contention that the FCC is attempting to enforce the lottery broadcast provision of the Criminal Code, it largely depends on the FCC's professed reliance on that provision. Without such reliance the Supreme Court's decision with respect to the Chain Broadcasting Regulations would directly apply. See p. 1114 infra.

71. The scope of the proposed rules would be limited only by the requirement that the agency must have reasonable grounds for denial of license and must not censor broadcasts. On the other hand, if the lottery broadcast provision is the sole basis, it seems clear that FCC action would be justified only with respect to broadcasts violative of that provision. See notes 12,14, and 16 supra.

72. See, e.g., Marks, supra note 69 , at 337 . See also note 111 infra.

73. See FCC, Supplemental Notice of Proposed Rule Making, supra note 18, §§ 2, 3. 
would seem preferable, and perhaps required. ${ }^{74}$ It is very doubtful whether the FCC can avoid its obligation to pass on the merits of each license application by issuing a general statement declaring that a particular type of broadcasting activity will invariably lead to license withdrawal. ${ }^{75}$ And the nonmandatory phraseology would probably shield the rules from prior judicial review. ${ }^{76}$ Finally, mandatory phrasing would add little to the effectiveness of the rules, since, as broadcasters are aware, the Commission could give decisive weight to the broadcast of lotteries even though formally considering such broadcasts only as one factor in arriving at a general evaluation of an applicant's qualifications. 77

Resort to the general licensing provisions as the statutory basis for the FCC's proposal, while readily supportable, gives rise to an apparent paradox in that the Commission, while relinquishing its direct claim to jurisdiction over lottery broadcasts, is still asserting authority to take action which will effectively compel broadcasters to comply with the radio lottery provision. This conundrum sharply points up the dual nature of license reprisals grounded on considera-

74. If, on the other hand, jurisdiction were derived directly from the lottery broadeast provision, the mandatory form would seem more appropriate, since the FCC would then be acting to fulfill a direct statutory responsibility to check the breadeast of lotteries. Under these conditions Section 312(a) of the Communications Act would appear to permit revocation of license solely because of a lottery broadcast infraction without the necessity of evaluating overall service; and a court might well reason that similar latitude should be allowed the Commission in refusing renewal.

75. The FCC itseif has insisted that denial of license is justified only where there has been an overall appraisal of the broadcasting service of the applicant. See note 12 supra. The judicial attitude is reflected in the Supreme Court's decisions in Columbia Broadcasting System v. United States, 316 U.S. 407 (1942) and National Broadcasting Co. v. United States, 319 U.S. 190 (1943), both dealing with the FCC's Chain Breadeasting Regulations. See note 99 and page 1114 infra. The Commission provided in those regulations that "No license shall be granted to a standard broadeast station" having certain types of contractual relationships with a network. FCC Regs. 3.101-3.10S, adopted 6 FED. REG. 2282 (1941), made effective 8 FED. REG. 7355 (1941). While the majority opinion in the $C B S$ case assumed that this meant automatic denial of license to any station not complying with the regulations, Justice Frankfurter insisted that this was not true, arguing that "Under $\$ 309$ of the Communications Act of 1934 the Commission is required to examine each application for a station license and to determine in each case whether a grant would serve public interest. . . No announcement of general licensing policy can relieve the Commission of its statutory obligation to examine each application for a license and determine whether a grant or denial is required by the public interest." 316 U.S. 407, 431-2 (1942). This view was apparently embodied in the majority opinion in the $N B C$ case. 319 U.S. 190, 225 (1943). It is interesting to note that, despite the vording of the regulations, the FCC insisted that "the applicant's right to a hearing on the question whether he does in fact propose to operate in the public interest is fully preserved" FCC, Report on Chain Broadcasting 85 (1941). In any case, it appears that the FCC does not intend to cast the proposed rules in imperative phraseology. See FCC, Supplemental Notice of Proposed Rule Making, supra note 18, \$\$2, 3.

76. See notes 97 and 99 infra.

77. The FCC has broad discretion in determining whether grant of a license will be in the public interest. See, e.g., FCC v. WOKO, 329 U.S. 223 (1946). 
tion of infractions of the lottery broadcast provision where such action is based only on the duty to evaluate an applicant's service to the public. On the one hand, such actions discharge the Commission's responsibility to license broadcasters as the public interest requires; on the other hand, they have the indisputable effect of enforcing the radio lottery provision. Focusing only on the latter aspect of such actions, opponents of the FCC's proposal may charge that the Commission is seeking to assert the very jurisdiction which it has renounced by retreating to the general licensing provisions as a statutory base, and is therefore attempting to usurp the enforcement function which it has implicitly conceded lies exclusively within the province of the Department of Justice. While posing a unique semantic problem, it seems unlikely that this argument will prove persuasive. Courts have never evinced an inclination to abrogate administrative acts, otherwise within an agency's authority, merely because they have the additional effect of compelling individuals to comply with public policies announced in the criminal statutes. ${ }^{78}$ If the Commission were to grant a license to a station which it believed was broadcasting a lottery in violation of Section 1304, it would be knowingly providing an instrument (the broadcast channel) essential to the commission of a crime. ${ }^{70}$

Thus, the FCC may find authority for administrative action against lottery broadcasts either in Section 1304 or in the general licensing provisions. The question remains, however, whether the choice of statutory ground will affect the availability of enforcement weapons.

\section{ENFORCEMENT WEAPONS}

Regulation of the conduct of broadcasters within the terms of the Communications Act is accomplished primarily through the FCC's exclusive power to grant construction permits and to license broadcasters. ${ }^{80}$ Through its control over the initial allocation of transmission frequencies the Commission may insure that the broadcasting privilege is entrusted only to persons who meet the standards prescribed by the Act; and through its power to revoke or refuse

78. See note 66 supra. In addition to charging lack of statutory authorization, opponents may claim that the FCC's proposal is barred because it calls for the imposition of "punitive" rather than "remedial" sanctions. This argument rests on an amorphous "dichotomy" producing uncertain legal consequences. See GeLLhorN, Administrutive LAW 322-52 (2d ed. 1947). But license reprisals under the Commission's proposal seem clearly "remedial", since license sanctions have uniformly been so labelled. Sce, c.g., Helvering v. Mitchell, 303 U.S. 391,399 (1938). Cf. Steuart \& Bro. v. Bowles, 322 U.S. 398 (1944); Perkins v. Brown, 53 F. Supp. 176 (S.D. Ga. 1943) ; Nelson v. Secretary of Agriculture, 131 F.2d 453 (7th Cir. 1943); Nichols \& Co. v. Secretary of Agriculture, 131 F.2d 651 (1st Cir. 1942); Wright v. SEC, 112 F.2d 89 (2d Cir. 1940). And even the characterization "punitive" need not prove fatal, for administrative sanctions so termed have occasionally been upheld by the courts. See, e.g., Passavant v. United States, 148 U.S. 214 (1893); Lloyd Sabaudo Societa v. Etling, 287 U.S. 329 (1932). See also GELL.HORN, supra, id.

79. See Radio Station With, Memorandum in Suprort of Proposeo Rulus 19 (Sept. 24, 1948).

80. Communications Act $\$ \S 307,309$ (a). 
to renew licenses, it may exercise continuing surveillance over the use of the franchise. In addition to this principal weapon, the Commission has power to investigate any activities of licensees which it believes may be detrimental to the public; ${ }^{81}$ to issue declaratory rulings based on the findings of investigations ; $^{\mathbf{2}}$ to obtain injunctions from district courts to restrain disobedience of appropriate agency orders; $\$ 3$ to request the Department of Justice to prosecute violations of any provisions of the Act; $; 4$ and to enact rules and regulations necessary to the performance of any of its functions. $\$$

Since these weapons are available to the FCC to carry out any of its functions under the Act, the Commission, if it derived jurisdiction directly from Section 316, could have resorted to this full arsenal to compel compliance with that provision. And if the FCC remains responsible for enforcement of Section 316 despite its removal, ${ }^{86}$ then that removal can hardly have the effect of diminishing the agency's capacity to effectuate such enforcement.

But if the FCC rests its proposal on the general licensing provisions, it encounters the argument that this provision can be enforced only by license reprisals, and that the Commission is thus foreclosed from using allegedly independent devices such as the proposed rules to inhibit lottery broadcasts. ${ }^{87}$ Accurate appraisal of this contention requires examination both of the nature of the licensing weapon and of the function of the proposed rules.

\section{The Licensing Weapon}

Ostensibly, the FCC's basic regulatory process is one whereby standards prescribed by the Act and by supplementary Commission regulations to govern the conduct of licensees are enforced through the administrative sanction of withdrawal of license. But since the essential standard to which licensees must conform is the FCC's conception of public service, any expression by the Commission of disapproval of a particular form of broadcasting activity is viewed by broadcasters as an indication of a specific criterion which will guide the Commission's licensing policy, and thus, backed by the implied threat of license reprisals, achieves the stature of an officially indorsed canon. ${ }^{89}$

81. Communications Act $\$ 403$. See also Stahlman v. FCC, 126 F.2d 124, 127 (App. D.C. 1942), ". . . [F]ull authority and power is given to the Commission with or without complaint to institute an inquiry concerning questions arising under the provisions of the Act or relating to its enforcement. This, we think includes authority to obtain the information necessary to discharge its proper functions, which would embrace an investigation aimed at the prevention or disclosure of practices contrary to the public interest."

82. Administrative Procedure Act $\$ 5(d), 60$ ST.AT. 239, 5 U.S.C. $\$ 1004$ (d) (1946).

83. Communications Act $\$ 401$ (b).

84. Id. $\$ 401(\mathrm{c})$.

55. Id. $§ 4(\mathrm{i}), 303(\mathrm{r})$. See p. 1112 infra.

S6. See p. 1104 supra.

87. See note 98 infra.

88. "The absolute power of the Commission does not even need the instrument of the written regulation to assert itself. ..." Even an informal expression of opinion by a Commissioner "is unmistakable notice to all broadcasters that they must conform their operations to such views or face the threat that their licenses may not be renewed" 
Recognizing the strong deterrent effect of unofficial but unequivocal statements as to its conception of broadcasting not in the public interest, ${ }^{80}$ the Commission has increasingly resorted to this device, rather than formally enacted rules, as a means of propounding specific standards to govern the conduct of licensees. ${ }^{90}$ Thus, the criteria for measuring the performance of broadcasters against the touchstone of public interest have been spelled out by the holdings or, more commonly, the dicta in Commission opinions in licensing proceedings ; by reports of investigations into particular broadcasting activities; and by policy statements, press releases, speeches by Commissioners, and letters to individual licensees. ${ }^{91}$ These devices have served not only as the vehicles for expounding standards but also as primary enforcement measures. A broadcaster transgressing a standard enunciated through one of these media may initially be restrained, for example, by a pointed letter of inquiry, an investigation followed by a warning, or a disapproving dictum in an order granting license renewal. In view of the severity of the ultimate sanction of license withdrawal underlying these measures, this informal regulatory technique has proven highly effective. ${ }^{02}$

Hearings before Committee on Interstate Commerce on S. 814, 78th Cong., 1st Sess. 112 (1944) (statement of W. S. Paley, president of CBS). Compare statement of Commissioner Fly, note 12 supra.

89. E.g., on May 4, 1931, prior to enactment of the lottery broadcast provision, the Federal Radio Commission, on the ground that it lacked authority to take such action, denied a petition requesting promulgation of an order banning the broadcast of lotteries. $1 \mathrm{~J}$. Rapio L. 346 (1931). Three days later the Commission issued a press release stating that "There exists a doubt that such [lottery] broadcasts are in the public intercst." N.Y.Times, May 8, 1931, p. 28, col. 3. The Commission later commented that "It is be" lieved that the warning had the effect of materially limiting this class of program, and in such instances as came to the attention of the commission after its issuance the programs were discontinued voluntarily by the station after the matter had been brought to its attention." 5 FRC ANn. REP. 9 (1931). See Caldwell, Legal Restrictions on the Contents of Broadcast Programs, 9 AIR L. Rev. 229, 231 (1938).

90. See Segal, supra note 12, at 368-71; Note 47 Col. L. Rev. 1041, 1043-7 (1947). See also Warner, Radio and TeLEvision Law 33-7 (1948).

91. See note 89 supra. See also Hearings before Committee on Interstate and Forcign Commerce on H.R. 5497, 77th Cong., 1st Sess. 644-5 (1942).

92. "All it [the FCC] had to do was put out a release, even a speech by an individual commissioner, disapproving of a particular type of program, and henceforth most or all the stations avoided that type of program. . . The threat of hearing and publicity was enough punishment to cause broadcasters to obey the views of the committee [Commission] . . . on what constitutes good programming." Ibid.

The FCC has felt impelled to adopt this oblique mode of regulation to avoid bringing into play the harsh sanction of license retraction, and has often requested Congress to provide it with a more moderate weapon to eliminate this necessity. E.g., Hearings before Connmittee on Interstate Commerce on S. 814, 78th Cong., 1st Sess. 43-4 (1944). An unsuccessful attempt was made to arm the Commission with authority to issue cease and desist orders in S. 1333, 80th Cong., 1st Sess., $\$ 14$ (1947). The FCC has thus far been reluctant to make use of the declaratory ruling device made available by $\$ 5(d)$ of the Administrative Procedure Act, supra note 82. See Harry S. Goodman, 4 PIKE \& Fiscrien RADio REg. 98, 99 (1948). 
Those who contend that enforcement action based on the FCC's licensing powers must be confined to exercise of the licensing weapon are actually acknowledging the Commission's authority to make use of all these measures to inhibit the broadcast of lotteries. Only where this procedure failed would the Commission resort to actual license reprisals. ${ }^{93}$

\section{Enactment of Rules}

Since the only practical effect of forbidding the issuance of rules to define the FCC's criteria for lottery broadcasts is to compel the agency to pronounce such standards informally, it is difficult to perceive what advantage broadcasters hope to gain by objecting to that aspect of the Commission's proposal. ${ }^{\text {at }}$ In the first place, formally enacted rules would provide a far more satisfactory guide for broadcasters who must seek to adapt their program formats to new requirements, and would eliminate much of the confusion which may result if the Commission is obliged to spell out its standards by ad hoc determination of lottery broadcast questions. ${ }^{35}$ And in the second place, broadcasters would lose the protection of the procedural safeguards surrounding the enactment of rules $^{96}$ and would forfeit whatever opportunity they may have to challenge the Commission's criteria for lottery broadcasts prior to their actual application in individual licensing proceedings. ${ }^{97}$

93. The FCC has formally announced that it will delete a station only as a last resort. C. Bruce 11cConnell, 6 F.C.C. 167, 174 (193S) ; Broollyn Broadeasting Corp., 4 F.C.C. 521 (1937).

94. Opposition to the enactment of rules as an enforcement device under the Commission's lottery broadcast proposal is not universal among broadeasters. The counsel for the National Broadcasting Company conceded that "It is in the interest of the broadcasters that their risks be minimized by removal of the uncertainty which exists in the interpretation of lottery laws. Therefore, if the Commission intends to apply Section 1304 of the United States Criminal Code in its licensing proceedings, it should make lnow $n$ in advance, as it proposes to do, the standards which it will follow." FCC, Offictal Reront of Proceenings in Matter of Promolgation of Rules Gomenitrig the Brondeast of LOTTERY INFORATATTON (Oct. 19, 1948).

95. The FCC itself has recognized these advantages of rule-malking as a means of defining standards. "We believe that the announcement of the principles we intend to apply in exercising our licensing power will expedite business and further the ends of justice... The formulation of a regulation in general terms is an important aid to consistency and predictability and does not prejudice any rights of the applicant. Godd administrative policy would seem to demand that such a statement of policy or rules and regulations be promulgated wherever sufficient information is available upon which they may be based." FCC, REPORT on Chan Broddcasting 85 (1941). By ignoring this counsel and continuing to rely primarily on informal modes for expounding program standards the Commission gains a maximum of procedural flexibility and avoids the possibility of prior judicial review. See notes 97 and 99 infra. The only apparent advantage to broadcasters is the possibility that if program standards are announced informally they may be applied less stringently.

96. The right of interested persons to adequate notice and an opportunity to have their views considered by the agency are guaranteed in connection with administrative promulgation of rules. Administrative Procedure Act $\$ 4,60$ STAT. 237, 5 U.S.C. $\$ 1001$ (1946). These rights, however, do not extend to interpretative rules or statements of policy. Ibid.

97. The Supreme Court authorized prior review of the Chain Broadeasting Regula- 
But the broadcasters' challenge necessitates consideration of whether enactment of the proposed rules would be a valid exercise of the FCC's rule-making authority. The scope of this authority is defined by Sections 303(r) and 4 (i) of the Communications Act, which authorize the Commission to issue rules "to carry out the provisions of this Act" and "necessary in the execution of its functions." If jurisdiction is derived solely from the general licensing provisions, the objection is encountered that, while the Commission's duty to regard the broad effect of a license grant on the public interest may permit consideration of lottery broadcast offenses in licensing proceedings, enactment of the proposed rules could be construed only as a correlative attempt to enforce a provision of the Criminal Code which the Commission has conceded it has no direct authority to enforce, and would therefore exceed these statutory restrictions on its rule-making power. ${ }^{98}$

The essential fallacy in this argument lies in the insistence that these rules constitute a direct and independent measure to enforce the radio lottery provision. ${ }^{90}$ While promulgation of these rules would undoubtedly restrain most

tions in Columbia Broadcasting System v. United States, 316 U.S. 407 (1942). In that case a divided Court found that the Chain Broadcasting Regulations were "orders" within the meaning of the Urgent Deficiencies Act, 38 Stat. 219, 220 (1913) as incorporated in the Communications Act through Section 402 (a), and consequently were reviewable prior to actual application of these standards in licensing proceedings. Following the reasoning of that decision, see note 99 infra, the lottery broadcast rules, which are to be patterned after the Chain Broadcasting Regulations (see FCC, Supplemental Notice of Proposed Rule Making, supra note $18, \S 4$ ) might similarly be subject to prior review. The $C B S$ case might be distinguished, however, since the networks did not have access to licensing proceedings through which the regulations might have been challenged.

98. "The non sequitur in the Commission's reasoning lies in its conclusion that, because it may have authority to consider violations of other statutes in passing on license applications in individual cases, it therefore has jurisdiction to issue rules generally defining what constitutes violations of those statutes. If the Commission had jurisdiction to issue regulations under Section 1304 of the Criminal Code, it equally would have jurisdiction to issue rules defining what, in its opinion, constitutes violations of other acts of Congress such as, for instance, the Sherman Act, the Robinson-Patman Act, the various 'fair trade practices' acts, etc. Obviously, that is not the Congressional intent." $A B C$, BRIEF, supra note 28 , at 26-7.

99. The Supreme Court's decision in Columbia Broadcasting System v. United States, 316 U.S. 407 (1942) (see note 97 supra), might appear to buttress this conception of rules as an independent enforcement weapon. In reaching the novel decision that the Chain Broadcasting Regulations were "orders" and therefore reviewable, the Court, after declaring that "The particular label placed upon [these regulations] is not conclusive," 316 U.S. 407, 416 (1942), observed that "numerous affiliated stations have conformed to the [Chain Broadcasting] regulations to avoid loss of their licenses with conscquent injury to appellant [CBS network]." Id. at 418. Having determined that "The regulations arc the effective instrument by which the injury complained of is wrought," $i d$. at 421 , the Court held that "an administrative order [which] has that effect ... is revicwable and it does not cease to be so merely because it is not certain whether the Commission will institute proceedings to enforce the penalty incurred under its regulations for non-compliance." Id. at 417-18.

Reliance on this decision to support the argument that the proposed lottery broadcast rules would be an autonomous enforcement measure and would therefore have to rest on 
licensees from broadcasting lotteries without actual resort to license reprisals, this deterrent effect would be achieved only because these rules would be backed by the ultimate threat of license withdrawal. 100 In reality, then, these rules would acquire operative significance solely because of their relation to the Commission's licensing function ${ }^{101}$ in defining standards which will govern

direct statutory authorization is of dubious merit for several reacons. First, the Court in this case was merely determining whether these regulations were reviewable as "orders", and was not concerned with their validity. Upon actual review of these regulations, the Court upheld them merely by ascertaining that the type of conduct with which they dealt was an appropriate subject for consideration in licensing proceedings-thus measuring the scope of the rule-making power by the range of the licensing weapon. National Broadcasting Company v. United States, 319 U.S. 190 (1943), see pp. 114-15 infro. Indeed, in the NBC majority opinion, Justice Frankfurter, who wrote the dissenting Grinion in the $C B S$ case, clearly embodied the views he expressed in that dissent: ". . . [The regulations] are merely an announcement to the public of what the Commission intends to do in passing upon future applications for licenses." Columbia Broadusting System v. United States, 316 U.S. 407, 431 (1942). ". . . [T] he regulations as such do not subject licensees to any sanctions." Id. at 437. Sec, e.g., National Broadeasting Co. v. United States, 319 U.S. 190, 225 (1943).

Second, the Court in the CBS case conceded that the deterrent effect of these rules was achieved through the threat of license reprisals (see above); but, being primarily cuncerned with the risk of irreparable injury, applied principles of equity to find a right of review in the appellant. 316 U.S. 407,415 (1942). As such, the holding can scarcely te employed to prevent administrative rule-making with respect to matters within the province of an agency's effective jurisdiction.

Finally, the majority opinion was clearly venturing no broad explication of the nature of administrative rules, but rather, rested its decision on a narrow, if somewhat fuzzy, distinction. Having adopted practical deterrent effect as the test of reviewability of administrative pronouncements, the Court must have realized that it was perilously close to authorizing prior judicial review of all administrative regulations, if not of all policy statements. The Court, therefore, found these regulations "peculiar" (id. at 425) in that they were "couched in terms of command and accompanied by an announcement of the Commission that the policy is one "which we will follow in exercising our licensing power...." and were therefore "controlling alike upon the Commission and all others whose rights may be affected by the Commission's execution of them." Id. at 422. Whether the imperative phraseology of the regulations is a realistic ground for distinguishing them from other pronouncements of standards of broadcasting conduct seems open to question. See dissenting opinion, 316 U.S. 407, 431-7 (1942); sce also National Bróadcasting Co. v. United States, 47 F.Supp. 940, 944 (S.D.N.Y. 1942), aff'd, 319 U.S. 190 (1943). The Commission itself insisted that there was no practical distinction, pointing out that "the applicant's right to a hearing on the question whether he does in fact propose to operate in the public interest is fully preserved." FCC, REFonr o:: Crar: Broadcasting 85 (1941). In any event, the Court's holding would do no more than indicate that if the proposed lottery broadcast rules were phrased in the imperative, they would be subject to prior judicial review; mere alteration of the phrasing to provide that specified types of giveaway programs would be considered lotteries contrary to the public interest would shield the rules from review, since there would then be no categorial statement that non-compliance would result in loss of license.

100. "It is common experience that men conform their conduct to regulations by governmental authority so as to avoid the unpleasant legal consequences which failure to conform entails." Columbia Broadcasting System v. United States, 316 U.S. 407, 418 (1942).

101. The judicial conception of the nature and extent of the FCC's investigatory power 
the grant of broadcasting franchises. Since these are stanclards which the FCC may properly apply in passing on license applications, ${ }^{102}$ the Commission would clearly appear to have authority to enact these rules as a supplementary measure contributing to the performance of its licensing function. ${ }^{103}$

The narrow interpretation of the Commission's rule-making authority urged by opponents of the proposed lottery broadcast rules is in sharp conflict with the broad construction placed upon those powers by the Supreme Court in National Broadcasting Company v. United States ${ }^{104}$ in which the Court upheld the Chain Broadcasting Regulations as a valid exercise of the Commission's rule-making authority. These regulations defined types of contractual relationships between stations and networks which the Commission, in view of the public policy expressed in the anti-trust laws, would deem contrary to the public interest in considering applications for broadcast licenses. ${ }^{105}$ To sustain

would seem to refute the contention that the potential deterrent effect of the proposed rules warrants artificially dissociating the rules from the licensing function in seeking statutory authorization. The investigatory power, like the rule-making power, is to be exercised only in connection with the provisions of the Communications Act. See id. $\$ 403$. And, like rules, investigations have an immediate deterrent effect on the broadcaster's concerned. See, e.g., note 92 supra. See also Hearings before Committec on Interstatc and Foreign Commerce on H.R. 5497, 77th Cong., 1st Sess. 644-5 (1942). The courts, nonetheless, recognizing the auxiliary nature of investigation as an administrative enforcement device, have confirmed the FCC's authority to investigate any matter which might properly be a subject for consideration in licensing proceedings. Stahlman v. FCC, 126 F.2d 124, 126 (App. D.C. 1942). See note 81 supra. There appears no substantial reason for refusittg to afford similar scope to the Commission's rule-making power.

102. See p. 1105 supra.

103. Authority for the rules may be found in Section 4(i) of the Communications Act, which empowers the FCC to "make such rules and regulations ... as may be necessary in the execution of its functions," and in Section $4(j)$, which provides that "The Commission may conduct its proceedings in such a manner as will best conduce to the proper dispatch of business and to the ends of justice."

In line with these statutory provisions, courts have afforded broad discretion to the FCC to determine the most feasible means for discharging its basic functions. Sce, c.g., Ward v. FCC, 108 F.2d 486, 491 (App.D.C. 1939). In fact, enactment of rules to defitre the standards by which the qualifications of applicants for licenses will be measured has been strongly encouraged. See Heitmeyer v. FCC, 95 F.2d 91, 98 (App.D.C. 1937). The judicial attitude toward rule-making as an administrative device for propounding standards of conduct within an agency's field of regulation is best expressed in SEC $v$. Chenery, 332 U.S. 194, 202 (1947): "Since the Commission [SEC], unlike a court, does have the ability to make new law prospectively through the exercise of its rule-making powers, it has less reason to rely upon ad hoc adjudication to formulate new standards of conduct within the framework of the Holding Company Act. The function of filling in the interstices of the Act should be performed, as much as possible, through this quasilegislative promulgation of rules to be applied in the future."

104. 319 U.S. 190 (1943).

105. See FCC, Report on Chain Broadcasting 46 (1941). "The prohibitions of the Sherman Act apply to broadcasting. The Commission, although not charged with the duty" of enforcing that law, should administer its regulatory powers with respect to broadcasting in the light of the purposes which the Sherman Act was designed to achieve." Sce also National Broadcasting Co. v. United States, 319 U.S. 190, 223-4 (1943). 
the Chain Broadcasting Regulations, it was necessary for the Court to establish two basic points : first, that the network arrangements denounced in the regulations were valid subjects for consideration by the FCC in passing on license applications; and second, that the Commission had authority to promulgate rules defining the standards it would enforce with respect to these arrangements in licensing proceedings. The decision clearly hinged on the former point. ${ }^{100}$ The Court found that, while Section 311 specifically empowered the FCC to weigh convictions under the anti-trust laws in licensing proceedings, this provision did not authorize consideration of unadjudicated infractions of those laws. ${ }^{107}$ However, the Court held that the FCC could consider monopolistic activity and unfair trade practices in passing on license applications solely on the ground that such conduct was contrary to the public interest in the use of broadcasting facilities. ${ }^{108}$ The fact that those activities might also be violative of the anti-trust laws would be of significance only in serving to confirm the Commission's judgment that such activities were socially harmful. Having found that the specified network practices were properly subject to scrutiny in licensing proceedings, the Court approved the promulgation of the regulations as a "particularization of the Commission's conception of the public interest sought to be safeguarded by Congress in enacting the Communications Act of 1934."109

106. The entire opinion was essentially devoted to establishing the FCC's general authority to cope with network practices. The Court did not clearly delineate between the licensing and rule-making weapons, apparently feeling that since they served a common regulatory purpose, their ranges were coextensive. See note 109 infra.

107. "... [T]he Act does not explicitly say that the Commission shall have power to deal with network practices found inimical to the public interest." National Broadeasting Co. v. United States, 319 U.S. 190, 218-9 (1943). See note 108 infra.

108. "A licensee charged with practices in contravention of this standard cannot continue to hold his license merely because his conduct is also in violation of the anti-trust laws and he has not yet been proceeded against and convicted. By clarifying in Section 311 the scope of the Commission's authority in dealing with persons convicted of violating the anti-trust laws, Congress can hardly be deemed to have limited the concept of 'public interest' so as to exclude all considerations relating to monopoly and unreasonable restraints upon commerce. Nothing in the provisions or history of the Act lends support to the inference that the Commission was denied the power to refuse a license to a station not operating in the 'public interest' merely because its misconduct happened to be an unconvicted violation of the anti-trust laws." Id. at 223. See also the district court opinion in this case, 47 F.Supp. 940, 944 (S.D.N.Y. 194?), aff'd, 319 U.S. 190 (1943).

109. 319 U.S. 190, 218 (1943). Section 303(i) of the Comunications Act empowers the FCC "to make special regulations applicable to radio stations engaged in chain broadcasting." If this provision had been accepted on its face, there could searcely have been much question as to the validity of the Chain Broadcasting Regulations. The Court, however, found that this provision alone would not support the regulations, since it did not bring network practices within the scope of the Commission's licensing power, which was the heart of the regulatory scheme. See note 107 supra. These practices were drawn within range of the licensing weapon by construing the provisions requiring the FCC to protect the public interest in radio as granting "not niggardly but expansive powers." Id. at 219. See also note 108 supra. The analysis of Section 303(i) was devoted to dispelling the notion that this provision restricted the otherwise broad powers of the Commis- 
The proposed lottery broadcast rules may be distinguished from the Chain Broadcasting Regulations in that the former define a type of broadcasting activity which the FCC apparently will consider detrimental to the public interest purely because it is inconsistent with a criminal statute, ${ }^{110}$ while the latter stigmatize certain network practices primarily on the basis of an independent determination by the Commission that such practices are injurious to the public.111 But this distinction would seem relevant only in determining whether the broadcast of lotteries is a proper subject for consideration in passing on license applications. Since the FCC has firm grounds on which to assert authority to weigh unadjudicated violations of the lottery broadcast provision

sion to only the technical and financial aspects of chain broadcasting. See $i d$, at 220-1.

Having ascertained that network arrangements were subject to regulation by the FCC, the Court never specifically considered the possibility that such regulation could only be achieved through exercise of the licensing power and not through the enactment of regtlations amplifying the standards which would govern the use of the licensing weapon. While not made explicit by the Court, it would appear that the specific act of issuing the regulations was considered to rest on Section 303(i) rather than on Section 303(r), the general rule-making provision. However, the Court emphasized that the FCC derived equally broad powers from both sections. After stating that "Congress endowed the Communications Commission with comprehensive powers to promote and realize the vast potentialities of radio," the Court cited both Sections $303(\mathrm{i})$ and $303(\mathrm{r})$ as sources of these expansive powers, and indicated that such powers stemmed from these provisions "individually and collectively.". Id. at 217 (emphasis added).

To contend that, while the FCC may control both network practices and lottery broadcasts through its licensing power, rules may not be issued with respect to the latter because lottery broadcasts were not specifically enumerated as subject to the rule-making power, would be to create the very type of functionless distinction the Court vigorously decried. "... [G]eneralities empty of all concrete considerations of the actual bearing of regulations promulgated by the Commission to the subject matter entrusted to it cannot strike down exercises of power by the Commission. While Congress did not give the Commission unfettered discretion to regulate all phases of the radio industry, it did not frustrate the purposes for which the Communications Act of 1934 was brought into being by attempting an itemized catalogue of the specific manifestations of the gencral problems for the solution of which it was establishing a regulatory agency." Id. at 219.

110. See FCC, Supplemental Notice of Proposed Rule Making, supra note 18, $\$ \$ 2,3$. See also p. 1106 stipra.

111. "While many of the network practices raise serious questions under the antitrust laws, our jurisdiction does not depend on a showing that they do in fact constitute at violation of the antitrust laws. ... We are issuing these regulations because we lave found that the network practices prevent the maximum utilization of radio facilities in the public interest." FCC, REPORT on ChaIN BroadCasting 83 n.3 (1941) (quoted with approval in National Broadcasting Co. v. United States, 319 U.S. 190, 223-4 (1943). Sce also note 108 supra.

The network arrangements proscribed by the Chain Broadcasting Regulations might well have violated the penal statutes forbidding monopolistic activity and unfair trade practices-and, indeed, this fact obviousiy received some consideration from the FCC. Sce note 105 supra. But the effect of such practices in restricting the use of broadcasting facillties was a matter which the FCC was especially equipped to observe and appraise. Thus, rather than relying directly on the Congressional determination that such practices were harmful to the public interest, the Commission grounded the regulations on its own judgment as to the effect of these practices on the public interest. But the statutory provisions 
in licensing proceedings, ${ }^{112}$ the $N B C$ decision would appear to affirm the Commission's right to promulgate rules enunciating the standards it will apply with respect to such conduct.

In seeking to avert the objection that enactment of the proposed rules would exceed its authority, the FCC may contend that the rules are entirely "interpretative" in nature. So denominated, the Commission might aver either that enactment of these rules need not be grounded on specific statutory authorization, or that their promulgation need not rest on any statutory base. ${ }^{113} \mathrm{Al}-$ though these lines of attack might have technical merit, it would appear inexpedient for the Commission to ensnare itself in a perplexing doctrinal web'st by placing reliance on the tag "interpretative". In the first place, as has been indicated, there are firm grounds for issuance of the proposed rules without resort to this argument. In the second place, any fear that a court might require specific authorization for the rules would seem groundless. Where, as in the case of the FCC, rule-making power has been delegated in general terms

imposing upon the FCC a broad responsibility for protecting the public interest in radio broadcasting can hardly be read to require such independent judgment by the Commission where Congress has expressed its own judgment as to the effect of particular types of broadcasting activity on the public interest.

112. See p. 1105 supra.

113. That the Commission may intend to advance this argument is suggested by its pointed insistence that "These proposed rules ... are entirely interpretative in nature and do not purport to add to or detract from the statutory prohibition imposed by Congress." FCC, Supplemental Notice of Proposed Rule Maling, supra note 18, \$5. Two objectives may be sought in urging the view that the rules are purely interpretative. First, as in the CBS case, the FCC may seek to avert prior judicial review of the rules. See note 99 sipra. And second, more pertinent to the instant discussion, the Commission may hope thereby to induce a reviewing court to apply more liberal standards in determining whether the promulgation of these rules is within the agency's rule-maling authority.

Two lines of approach might be adopted in connection with this second point. First, if the Commission expected that specific authorization would be required if the rules were not classified as interpretative, it might gain access to implied authority by affining that tag. See Davis, Administrative Rules-Interpretatize, Lcgislatize ond Rctrodetizi, 57 YALE L. J. 919, 928-34 (1948). But it seems unnecessary to wrangle over labels on this score. See p. 1117 infra.

Second, the FCC might urge that if the proposed rules are interpretative in nature, statutory authorization is not required to support their enactment. Several cases may be cited to uphold this argument. See Davis, siupra, at 928-34. Section 9(a) of the Administrative Procedure Act might also be construed to lend weight to this contention. Sce note 114 infra. To argue that the promulgation of interpretative rules need not be grounded on statutory authorization to issue such pronouncements would not, of course, be to argue that the FCC may regulate matters beyond the defined scope of its jurisdiction. The regulatory policy expounded in such rules would be subject to judicial reviev when implemented by the Commission in licensing proceedings.

While this conception of the legal consequences of labelling a rule as interpretative may be sound, it appears that the FCC would have difficulty persuading a reviewing court to tag the rules as interpretative. See notes 114 and 118 infro.

114. While federal statutes and court decisions recognize different eategories of administrative rules, they fail to provide a sufficient basis for distinguishing between these classes or for determining, with any degree of certainty, the different legal consequences 
encompassing the full range of the agency's regulatory jurisdiction, the distinction between express and implied authorization becomes virtually meaningless. ${ }^{115}$ And in any event, it seems clear that administrative rules, however labelled, may rest upon either specific or implied statutory authority. ${ }^{110}$ And finally, while it would be of advantage to the Commission to free this type of rule completely from the requirement of statutory authorization, the unlikelihood of success seems sufficiently great to discourage the attempt in this instance. For this argument would encounter an imposing barrier in the $N B C$ decision, in which the Supreme Court held that the Chain Broadcasting Regtu-

which result from attaching a particular label. The Administrative Procedure Act, supro note 82, refers to "interpretative rules" and "rules of agency organization, procedure, or practice" in Section 4(a), and exempts both of these classes of rules from procedural requirements applicable to rules not within these categories. In Section 3(a) it distinguishes between "substantive rules" and "statements of general policy or interpretations formulated by the agency for the guidance of the public." The Act, however, offers no definition of these different types of rules. Professor K. C. Davis distinguishes between "legislative" and "interpretative" rules, and points out that "According to the theory, legislative rules are the product of a power to create new law, and interpretative rules are the product of interpretation of previously existing law. Legislative rules may change the law, but interpretative rules merely clarify the law they interpret." Davis, supra note 113 , at 928. Rules defining agency procedure would appear to constitute a third category.

"Legislative" rules are generally held valid only when grounded on express or implied statutory authority, when the proper procedure has been followed in enacting them, and when there is substantial evidence to support the reasonableness of the action. Id. at 931 . When these requirements are met, the theory is that "reviewing courts may no more substitute their judgment on policies declared by legislative rules than they may substitute their judgment on policies declared by statutes." Id. at 929 . On the other hand, agency power to issue interpretative rules has often been considered inherent rather than dependent on statutory grant. Id. at 930 . Judicial control has been retained, however, since "courts often deem themselves free to substitute their judgment as to content of interpretative rules." Id. at 929.

The Administrative Procedure Act might be construed to permit the issuance of interpretative rules without statutory authorization. Section 9 (a) provides that "No... substantive rule ... [shall] be issued except within jurisdiction delegated to the agency and as authorized by law." (Emphasis added.) The Act specifically recognizes interpretative rules as a unique category, and in Section 3(a) appears to differentiate such rules from substantive rules. It might be argued, therefore, that, by exclusion, Section 9(a) exempts interpretative rules from the requirement of statutory authorization which it imposes on substantive rules. But while the wording of the statute may serve this argument, the House committee report on the Act indicates an intent that Section 9(a) have general application to administrative actions including all types of agency pronouncements. H. R. Rep. No. 1980, 79th Cong., 2d Sess. (1946).

115. The House-committee reporting the Administrative Procedure Act explicitly pointed out that rule-making power may be delegated to an administrative agency in either specific or general terms. H. R. Rep. No. 1980, 79th Cong., 2d Sess. (1946). The grtut of such powers to the FCC is of the latter type. See p. 1112 supra. The very generality of the grant would seem to preclude the possibility of requiring specific authorization for the enactment of rules.

116. See Davis, supra note 113, at 929. 
lations, to which the FCC has analogized the proposed rules, ${ }^{217}$ were legislative in character and had to rest upon a statutory base. ${ }^{118}$

\section{Conclusion}

In view of the sharp opposition encountered by the FCC's lottery broadcast proposal, it is interesting to note the essentially conservative character of this plan.

While suggesting a new departure in program control, the FCC's proposal does not represent so much an extension of the Commission's supervisory powers as an attempt to close a gap which has developed well behind the outermost frontiers of the area over which it has exerted control. Since the FCC has utilized its licensing powers to curb programming practices merely because the Commission has deemed them detrimental to the public interest, ${ }^{110}$ it would hardly seem a radical innovation for the custodian of the publicly owned air waves to check the broadcast of programs which Congress has branded as

117. FCC, Supplemental Notice of Proposed Rule Mraking, supra note $18, \$ 4$.

118. While the Supreme Court, in reviewing the Chain Broadeasting Regulations in the $N B C$ case, tacitly rejected the characterization of those regulations advanced in the $C B S$ opinion, see note 99 stpra, it nevertheless held that "Our duty is at an end when we find that the action of the Commission was based upon findings supported by evidence, and was made pursuant to authority granted by Congress. . . The responsibility belongs to the Congress for the valid grant of legislatize authority and to the Commission for its exercise." 319 U.S. 190, 224 (1942). (Emphasis added).

Although the argument that interpretative rules need not be based on statutory authorization might have merit, it would seem difficult for the Commission, in the face of this holding, to convince a court that the lottery broadcast rules were interpretative. The FCC might, however, attempt to distinguish the proposed lottery broadeast rules from the Chain Broadcasting Regulations in several ways. First, the Commission may cast the rules in a different form than the regulations, see note 99 supra, and attempt to establish that the mandatory nature of the regulations was a vital factor in the NBC as well as the $C B S$ case. Second, it might point out that the Chain Broadeasting Regulations were enacted on the basis of an independent study of the effects of network practices on broadcasting service, and did not purport to rest solely on a legislative prohibition, while the proposed rules apparently do. See p. 1106 supra. Consequently, the FCC might argue these rules are more clearly interpretative of existing law, and do not create broadeast standards which have not already been enunciated in fairly specific terms by statute. Finally, the Commission might contend, as it did unsuccessfully in the CBS case, that there is no operative distinction between such rules and a press release containing the same information. Rather, it might urge, the difference lies only in the label affixed and in the consequences courts attach to those labels. Sec, e.g., Hearst Radio v. FCC, 167 F.2d 225 (App. D.C. 1948) (court held that the Commission's Bltse Book, see note 15 sisfro, defining standards of program service to be applied in licensing proceedings, were nat rules). It might be pointed out that the Supreme Court in the CBS case, 316 U.S. 407, 422 (1942), distinguished the Chain Broadcasting Regulations from a press release on the grounds that the regulations were "avowedly adopted in the exercise of that [rule-maling] nower" and were "couched in terms of command" The FCC might suggest that both grounds are inconsistent with the Court's expressed unconcern with form rather than substance. See note 99 sipra.

119. See notes 12 and 16 supra. 
illicit. Indeed, unless the statutory proscription against lottery broadcasts is to be rendered impotent, such action seems imperative. ${ }^{120}$

Particularly difficult to comprehend is the objection to the enactment of rules as an enforcement device, since broadcasters themselves have been the harshest critics of the Commission's oblique technique of regulation "by the raised eyebrow."121 This challenge may be merely a makeweight advanced in the hope either that it will further discourage the already hesitant Commission, or that if the agency can at least be induced to propound its lottery broadcast standards informally, it will apply them less assidutously. It seems likely that once the FCC's authority and determination to tundertake administrative action to bar lottery broadcasts are established, many broadcasters will heartily indorse the formal promulgation of rules delineating this new policy. ${ }^{122}$

Despite the failure of Congress specifically to impose responsibility for effectuating the radio lottery provision on the FCC, there appears ample stpport for the Commission's view that it is charged with this duty, and that enactment of the proposed rules would be an appropriate means of fulfilling this obligation.

120. See note 40 supra.

121. Hearings before Committee on Interstate Commerce on S. 814, 78th Cong, 1 st Sess. 112 (1944). See also Hearings before Committee on Interstate and Forcign Commerce on H. R. 5497, 77th Cong., 2d Sess. 645 (1942).

122. See, e.g., note 94 supra. 